\title{
異なる環境に暴露したアルミニウムにおける水素の挙動
}

\author{
鹿川 隆廣 $*$. 伊藤 吾朗 $* *$
}

Journal of Japan Institute of Light Metals, Vol. 60, No. 9 (2010), pp. 433-437

\section{Behavior of hydrogen in aluminum exposed in different atmospheres}

\author{
Takahiro SHIKAGAWA* and Goroh ITOH**
}

\begin{abstract}
Hydrogen in aluminum alloys frequently causes degradation of mechanical properties and surface quality of the products. Thus, the behavior of hydrogen in aluminum has been extensively studied. However, there has been an appreciable controversy in whether hydrogen intrudes the aluminum when exposed to air with moisture. In this study, hydrogen behavior in a pure aluminum foil that had been dehydrogenated and subsequently exposed to mainly air at temperatures ranging from room temperature to $550^{\circ} \mathrm{C}$ was analyzed by means of TDS, thermal desorption spectroscopy. In the specimens exposed to air and water at room temperature, hydrogen evolution was clearly observed at temperatures above about $450^{\circ} \mathrm{C}$ in the TDS spectra. This means that moisture at the specimen surface was converted to atomic hydrogen through the reaction with aluminum which subsequently diffuses into the specimen and is trapped by certain sites. Additionally, the specimens were annealed at several temperatures and humidities for $1 \mathrm{~h}$. In the specimens exposed to air at different temperatures and humidity, the amount of hydrogen contained in the specimens was increased as the humidity and the temperature. Two peaks were seen at about 450 and $550^{\circ} \mathrm{C}$ in the spectra of the specimens containing large amount of hydrogen, and were found to correspond to the hydrogen trapped by dislocations and micro pores, respectively.
\end{abstract}

(Received February 8, 2010 Accepted May 27, 2010)

Keywords: pure Al, aluminum, hydrogen, thermal desorption spectroscopy, dehydrogenation, atmosphere

\section{1. 緒言}

近年，次世代燃料として温室効果ガスを排出しないクリー ンエネルギーである水素が注目され，水素を利用した燃料電 池自動車が実用化されつつある。燃料電池自動車では, 燃料 として使用する水素を貯蔵するための高圧水素容器が必要で あり，そのライナ材としてアルミニウム合金が利用されてい る ${ }^{1 ｝ \text { 。しかし，金属材料は微量の水素によって脆化（水素助 }$ 長脆化）を起こす懸念がある。アルミニウムでは, 鋳造, 溶 解時に大気中の水分とアルミニウムが反応し生成した水素が 溶湯中に拡散する。その後, 加工・熱処理の段階で拡散した 水素がポアやブリスタ（ふくれ）を形成し，材料の諸性質を 低下させると考えられる ${ }^{2)}$ 。一方, 固体状態においても上記 の反応により湿潤大気中から ${ }^{3)}$, あるいは高圧水素雾囲気か $ら^{4)}$ 水素が侵入し，一部の合金で脆化を生じることが知られ ている。そのため, アルミニウム中に内在する水素の挙動に 関する研究が数多く報告されている。それらによれば, 拡散 した水素はポアやブリスタに含まれる以外に転位 ${ }^{5), 6)}$ や第二 相粒子 5) などのトラップサイトに捕捉されるといわれてい る。また, 電気的なチャージ法により強制的に水素を導入し たアルミニウムにおいても, 同様に転位や空孔, ブリス夕に

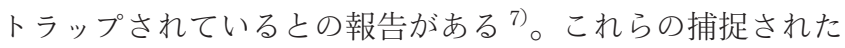

水素はある条件を満たすとトラップサイトを離れ，試料外へ 放出されるとの報告屯ある。梅田ら ${ }^{8 ）}$ は, $99.99 \%$ および 99.7\%の純アルミニウムをべースとした $\mathrm{Al}-\mathrm{Mg}$ 合金を $200 \sim 500^{\circ} \mathrm{C}$ で $4 \mathrm{~h}$ 等時焼なましした後の内在水素量を比較し た結果, 焼なまし温度が高くなるにつれ試料に内在する水素 量が減少すると報告している。一方で, 固相のアルミニウム 中に水素が侵入する過程については, 酸化膜の破れ等により 生じたアルミニゥムの新生面と水分が反応し原子状の水素が 侵入すると考えられている ${ }^{8)}$ 。このように，水素が大気を始 めとする雾囲気からアルミニウム中に侵入するのか, 放出さ れるのかについては検討の余地が残っている。

そこで本研究では, 基礎的な見地から, 第二相粒子がほと んど存在しない $99.99 \%$ の純アルミニウム箔を用い, 箔中の 不純物水素をあらかじめ除き，その後異なる環境に暴露する ことにより侵入する水素の挙動を昇温脱離分析（TDS： Thermal Desorption Spectroscopy）により調べた。ここでの不 純物水素除去（脱水素）も TDS 装置を用い, 試料中の水素 の脱離を確認しながら行った。なお, TDS は超高真空中で試 料を加熱する際に放出される水素量を逐次分析することで, 試料中の総水素量の測定のほかに, 得られる昇温脱離スペク トルにおける各ピーク温度からトラップサイトの推定を行う ことができる。

\footnotetext{
*茨城大学大学院理工学研究科大学院生（† 316-8511 茨城県日立市中成沢町 4-12-1)。Graduate Student, Graduate School of Ibaraki University（4-12-1 Naka-Narusawa, Hitachi-shi, Ibaraki, 316-8511).E-mail: 08nd102t@hcs.ibaraki.ac.jp

** 茨城大学工学部機械工学科 (日立市)。Department of Mechanical Engineering, Ibaraki University（Hitachi-shi, Ibaraki).
} 


\section{2. 実験方法}

試料は, Table 1 に組成を示す $110 \mu \mathrm{m}$ 厚の $99.99 \%$ の純ア ルミニウム箔を用いた。この試料は溶解，半連続 DC 鋳造 （鋳塊サイズは, $60 \mathrm{~mm}$ 厚 $\times 200 \mathrm{~mm}$ 幅 $\times$ 約 $300 \mathrm{~mm}$ 長さ), 均質化処理 $\left(590^{\circ} \mathrm{C}, 6 \mathrm{~h}\right)$, 面削 (片面 $5 \mathrm{~mm}$ ずつ), 熱間圧 延 $(10 \mathrm{~mm}$ 厚まで $)$, 冷間圧延 $(130 \mu \mathrm{m}$ まで $)$, 中間焼なまし $\left(250^{\circ} \mathrm{C}, 2 \mathrm{~h}\right), 15 \%$ 付加圧延, そして $560^{\circ} \mathrm{C} て ゙ ~ 1 \mathrm{~h}$ の最終焼な ましを経て作製されている。この箔から長さ $15 \mathrm{~mm}$, 幅 $15 \mathrm{~mm}$ の試験片を切出し, アセトンおよび純水で洗浄, 乾燥 を行った。

Fig. 1 に本実験の概略図を示す。試験片中の不純物水素を あらかじめ除く処理（Fig. 1 (1)）として，TDS 装置を用いて 超高真空チャンバ (圧力 $\left.<10^{-7} \mathrm{~Pa}\right)$ 内にて, 放出される水素 （質量数： $\mathrm{m} / \mathrm{e}=2$ ）を四重極質量分析計で測定しながら, $20^{\circ} \mathrm{C} / \mathrm{min}$ の昇温速度で $550^{\circ} \mathrm{C}$ まで加熱した。なお, 試験片表 面に吸着した水分，屯しくは水和膜に含まれる水分の影響を なるべく少なくするため，上記の加熱の前に同じチャンバ内 で $100^{\circ} \mathrm{C}, 30 \mathrm{~min}$ の予備加熱を行った。 $550^{\circ} \mathrm{C}$ までの加熱 (以 下では本加熱之呼ぶ）後, 測定開始温度までの冷却を確認 し, Fig. 1 (2) の TDS を行い, 試験片中の内在水素の脱離を 確認した。この TDS を含め, 以下のすべての TDS は上記の 脱水素処理の場合と同じ予備加熱・本加熱の条件で（ただ し, 一部の実験では本加熱の最高温度を $600^{\circ} \mathrm{C}$ とた）行っ た。この（1)，（2）で得られた水素脱離スペクトルを Fig. 2 に示す。これより，(1）の脱水素処理によって, 不純物水素 はほぼ除去されたことがわかる。また, 脱水素前後の水素量 は（1），(2）のスペクトルよりそれぞれ 0.26, 0.02 mass ppm と

Table 1 Chemical composition of the pure aluminum specimen in mass ppm

\begin{tabular}{c|c|c|c|c|c|c|c}
\hline \hline $\mathrm{Si}$ & $\mathrm{Fe}$ & $\mathrm{Cu}$ & $\mathrm{Mn}$ & $\mathrm{Zn}$ & $\mathrm{Ga}$ & $\mathrm{Pb}$ & $\mathrm{H}$ \\
\hline 15 & 9 & 26 & 3 & 12 & 2 & 1 & 0.11 \\
\hline
\end{tabular}

算出された。脱水素前の水素量は Table 1 に示す鋳塊時の水 素量（0.11 mass ppm）よりも多く, 後に詳しく述べるが焼なま しにより 0.02 mass ppm 以上の水素は材料外に放出されると考 えられるので，この違いは測定法の違いによると判断される。

次に,この脱水素処理を行った試験片に対して Fig. 1 (a) に示す（3），（5），(7），（9）の各環境への暴露処理を施した 後, TDSを行った。ここで, (5), （7）の暴露により水素が 試験片中に侵入することがわかった（後述）ので, 試験片中 の水素の挙動に及ぼす暴露大気の温度执よび湿度の影響を詳 しく調べるため，それぞれ Fig. 1（b)，（c）に示す手順に基 づきTDSを行った。すなわち, Fig. 1 の（1），(2）の後に, Fig. 1（b）の（12）では実験室温度 $\left(25^{\circ} \mathrm{C}\right)$ における相対湿 度（以下 RH と略す） 30 50\% で一定に保った大気を炉内に 循環させながら $500^{\circ} \mathrm{C} て ゙ 1 \mathrm{~h}$ の焼なましを, Fig. 1 (c) の（15）

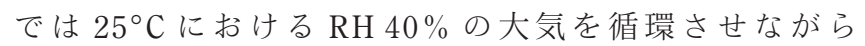
200 $500^{\circ} \mathrm{C}$ の各温度で $1 \mathrm{~h}$ の等時焼なましを，それぞれ行い， 最終的に（13），(16）でTDSを行った。な扮，本研究で行っ たTDS（Fig. 1（1）の脱水素処理を含む）では，測定後の バックグラウンド（チャンバからの水素放出）測定のために, 予備加熱なしで本測定と同じ条件（昇温速度, 到達温度）で 加熱測定し, 結果はすべてバックグラウンド除去後のデータ で示した。

\section{3. 実験結果および考察}

\section{1 大気および水からの水素の侵入挙動}

Fig. 3 に Fig. 1 (a) の (4), (6), (8), (10) の各 TDS で 得られた水素脱離スペクトルを示す。（4）の結果から, 超高 真空では水素が侵入しないことがわかる。これと比べて, （6），(8)，（10）では全体に水素放出量が多く, とくに $400^{\circ} \mathrm{C}$ を超えると顕著になり, 水素の放出総量（脱離曲線の下の領 域の面積）が大気，および純水に暴露することにより増加す ることが明らかである。ただし，(6)，（8），(10）の各放出 水素量はいずれも脱水素処理前 (Fig. 2 (1)) に比べると少な くなっている（Fig. 2 と Fig. 3 の縦軸のフルスケールの違いに 注意)。

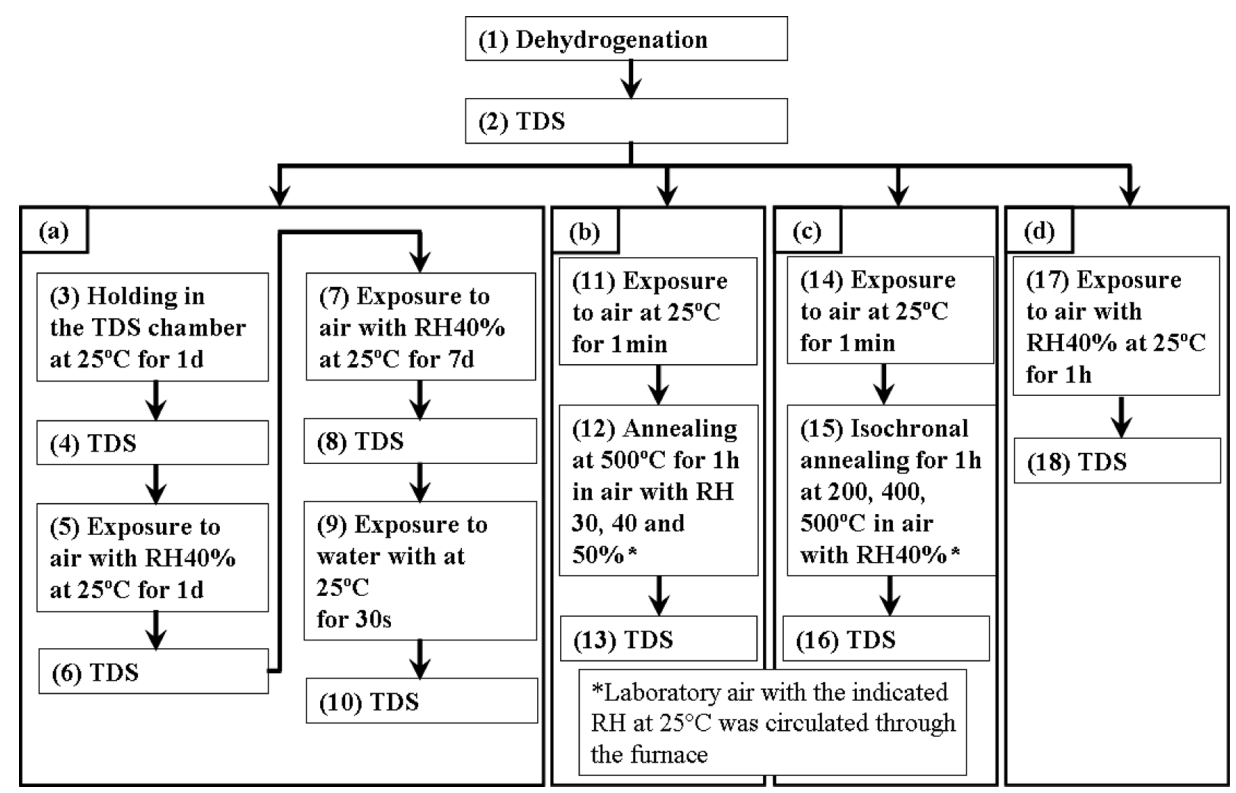

Fig. 1 Schematic diagram showing four series of experimental procedures (a-d). RH: relative humidity 


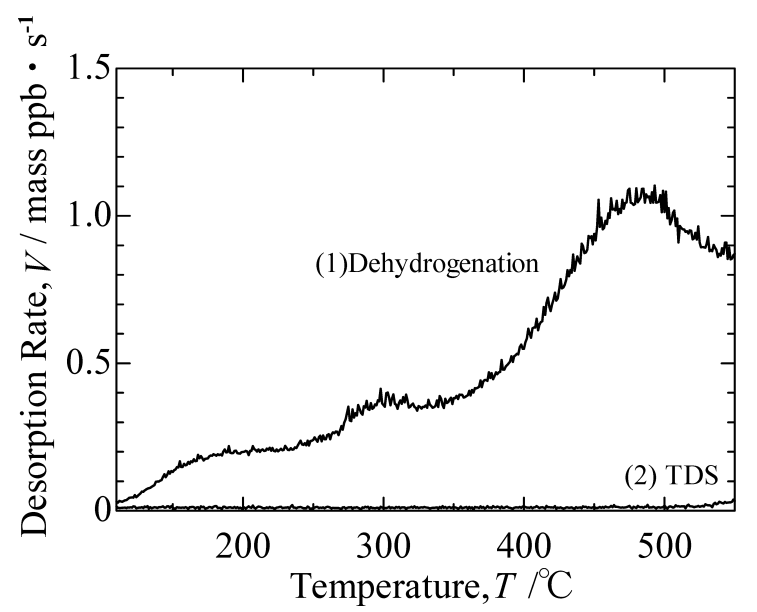

Fig. 2 Thermal desorption spectra for hydrogen gas taken from steps (1) and (2) shown in Fig. 1.

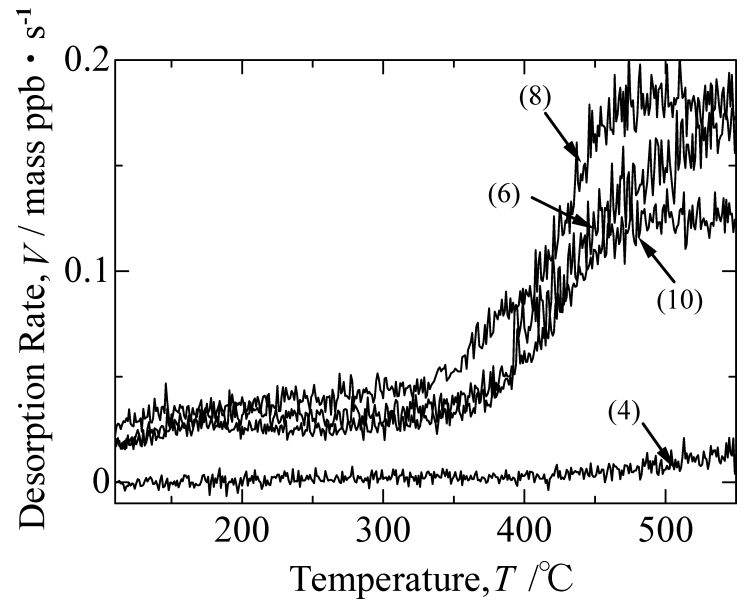

Fig. 3 Thermal desorption spectra for hydrogen gas taken from the indicated steps shown in Fig. 1 (a).

水蒸気を含む大気および純水に暴露された試験片の表面 には水分が付着したり, 水和膜中に水分が含まれていたりす る ${ }^{9)}$ が, そ机らの水分は加熱中に $\mathrm{H}_{2} \mathrm{O} や \mathrm{H}_{2}$ として試験片外 一抜け出るあのと, アルミニウムと反応し試験片中へ水素が 侵入し, 内部にトラップされるあのがあげられ, 後者が放出 総量に影響したものと考えられる。

\section{2 焼なまし時の水素の侵入挙動}

Fig. 4 に Fig. 1 (b)（12）の $500^{\circ} \mathrm{C} て ゙ 1 \mathrm{~h} の$ 焼なまし後に Fig. 1 （b）（13）の TDSを行ったときに得られたスペクトル を示す。いずれのスペクトルにも $450^{\circ} \mathrm{C}$ および $550^{\circ} \mathrm{C}$ 付近に 放出ピークが見られ，放出量は Fig. 1 (a) の室温に暴露した 場合（Fig. 3 （6)，（8））に比へ著しく多い。また， $450^{\circ} \mathrm{C}$ 付 近のピークに㧍ける水素の放出速度（ピーク高さ）は雾囲気 の湿度が高いほど高い。これは, 湿度が高くなることで侵入 する水素が増加するためと考えられる。

内在水素を含む $4 \mathrm{~N}$ の純了ルミニウム箔について, 泉 ${ }^{6)}$ は （1）式を用いてトラップサイトからの水素の脱離エネルギー の算出を行っている。

$$
\frac{d \ln \left(\beta / T_{p}^{2}\right)}{d\left(1 / T_{p}\right)}=-\frac{E_{d}}{R}
$$

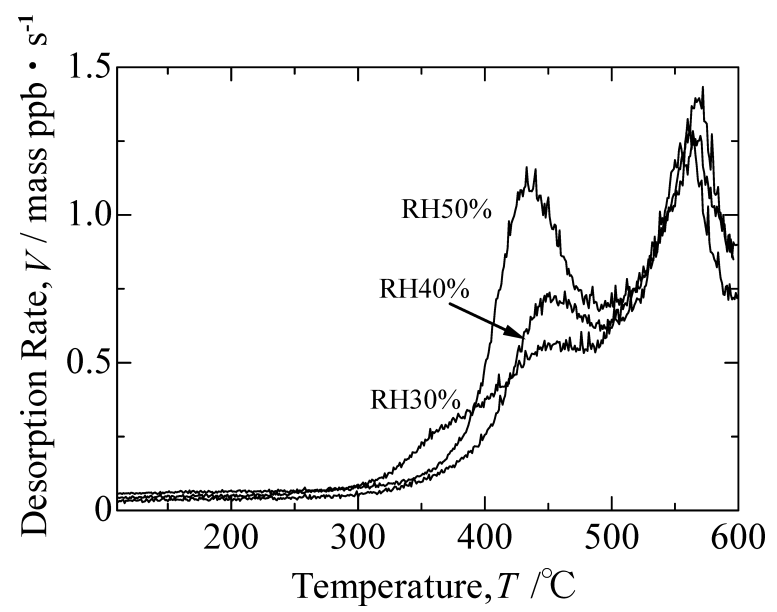

Fig. 4 Thermal desorption spectra for hydrogen gas taken from step (13) shown in Fig. 1 (b).

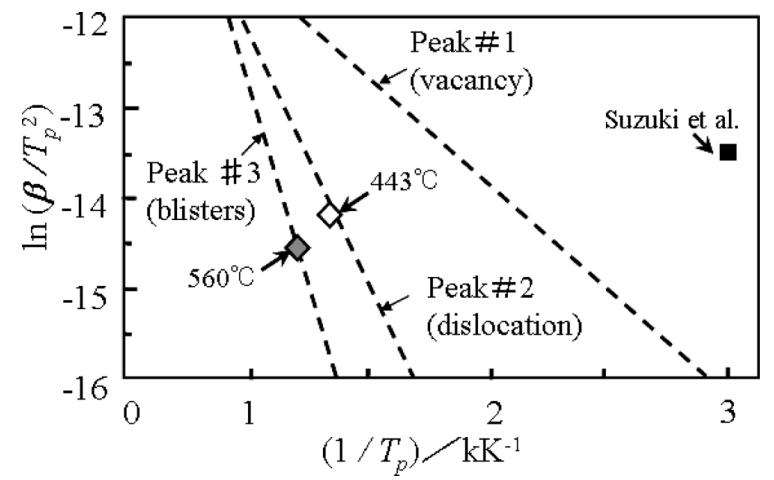

Fig. 5 Relationship between $\ln \left(\beta / T_{p}^{2}\right)$ and $1 / T_{p}$. The data of the present study of Fig. 4 and of the report by Suzuki et $a l^{7)}$ are plotted in the graph.

ここで， $E_{d}$ は脱離エネルギー $(\mathrm{J} / \mathrm{mol}), \quad \beta$ は昇温速度 $(\mathrm{K} / \mathrm{s}), T_{p}$ はピーク温度 $(\mathrm{K}), R$ は気体定数 $(\mathrm{J} /(\mathrm{mol} \cdot \mathrm{K}))$ を それぞれ示す。

彼は，(1）式における $\beta$ を変化させたときの $T_{p}$ の変化か ら, 空孔, 転位, ブリスタの 3 種類のトラップサイトからの 水素の脱離エネルギーを求めている。彼の得た 3 つの直線関 係に本実験の $\beta(=0.33 \mathrm{~K} / \mathrm{s})$ と Fig. 4 中の低温側のピーク温 度 $T_{p}$ （3つのスペクトルについて平均をとり $443^{\circ} \mathrm{C}$ とた） および高温側のピーク温度 $T_{p}\left(=560^{\circ} \mathrm{C}\right)$ をプロットした結 果をFig. 5 に示す。この結果から, 低温側のピークは転位に トラップされた場合の直線上に, 高温側はブリスタの場合の 直線上にそれぞれ位置することがわかる。 $443^{\circ} \mathrm{C}$ はアルミニ ウムの一般的な再結晶温度よりはるかに高いので, 水素を卜 ラップするのに十分な密度の転位が存在するかどうかを考察 する必要がある。

泉ら ${ }^{10)}$ による今回と同様のプロセスで作製し，今回用 いた箔に近い水素量の箔は主に小角粒界で囲まれた立方体方 位粒から成る。大傾角粒を除いて粒径を算出すると約 $200 \mu \mathrm{m}$ $\left(1 \mathrm{~cm}^{3}\right.$ 中の小角粒界長さ $\left.9.1 \times 10^{3} \mathrm{~cm}\right)$ となる。ここで, 小角

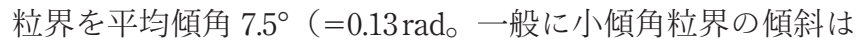
$15^{\circ}$ 未満といわれているので $0^{\circ}$ と $15^{\circ}$ の平均の $7.5^{\circ}$ とした） の傾角粒界之近似し, 箔面に垂直に貫通する刃状転位加ら成 ると仮定し, 傾角 $\theta(\mathrm{rad})$ と転位間隔 $h$ の間には, 


$$
\begin{aligned}
\theta= & \tan ^{-1} \frac{b}{h} \cong \frac{b}{h} \\
& \quad(b \text { はバーガースベクトルの大きさ) }
\end{aligned}
$$

の関係 ${ }^{11)}$ があるので, $h=1.1 \times 10^{-7} \mathrm{~cm}$ となる。この $h$ と前述 の $1 \mathrm{~cm}^{3}$ 中の小角粒界長さから, 箔 $1 \mathrm{~cm}^{3}$ 中の転位数 $8.4 \times 10^{10}$ 本が得られ，さらに各転位が箔を貫通していることから転位 密度 $\rho$ は $9.3 \times 10^{8} \mathrm{~cm} / \mathrm{cm}^{3}$ となる。このときの $1 \mathrm{~cm}^{3}$ 中の転位 芯格子サイト数は $\rho / b$ で求められるので $6.5 \times 10^{16}$ 個となる。 これに対し, 今回問題としているピークから放出される水素 量を最も放出量の多い Fig. 4 の RH $50 \%$ で算出する $\left(360^{\circ} \mathrm{C}<\right.$ $\left.T<490^{\circ} \mathrm{C}\right)$ と, 0.065 mass ppm $\left(=1.7 \mathrm{~mol} \mathrm{ppm}, 1 \mathrm{~cm}^{3}\right.$ 中に $1.7 \times 10^{18}$ 個）となり上記格子サイト数の 26 倍となる。転位芯 のまわりに多数の固溶水素が雾囲気を作っている可能性や, Fig. 2 の結果に関連して述べたようにTDSでは見かけ上，実 際より多量に水素が検出される可能性がある。他方，水素の 平衡固溶量から考察すると，市村ら ${ }^{12)}$ の結果を基に水素の $443^{\circ} \mathrm{C}$ での固溶量は $0.086 \mathrm{~mol} \mathrm{ppm}\left(1 \mathrm{~cm}^{3}\right.$ に $8.5 \times 10^{16}$ 個 $)$ とな り，上述の転位芯格子サイト数之同程度になる。この水素が 格子間と転位などのトラップサイトによ゙のように分配される かはわからない。また, TDS 装置内の超高真空中での固溶量 あわからないが, 問題とする TDS 時のピーク温度での水素原 子数は当然これより少ないと考えてよい。したがって，この 水素原子数よりも上述の転位芯の格子サイト数のほうが多い

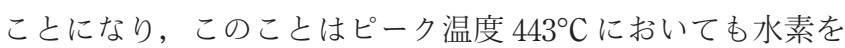
トラップするのに十分な量の転位が存在することを意味する。 6066 合金 $\mathrm{T} 6$ 材について，水素放出挙動に及ぼす变形の影 響を本研究と同じ TDS の測定条件で調べた結果 ${ }^{13)}$ では, 变 形により約 $460^{\circ} \mathrm{C}$ に新しいピークが生じるとされている。こ のことも本研究の $443^{\circ} \mathrm{C}$ のピークが転位にトラップされたピー クであることを支持する。一方，鈴木ら ${ }^{7)}$ は，電気的に水素 をチャージした $99 \%$ の純アルミニウムについてガスクロマト グラフにより得られた水素放出スペクトルにおいて, 著しく 低い約 $60^{\circ} \mathrm{C}$ のピークを転位にトラップされた水素のピークと 推定している。そこでまず，転位密度と水素放出量について 考察する。彼らのピーク温度 $(333 \mathrm{~K})$ と昇温速度 $(0.056 \mathrm{~K} / \mathrm{s})$ を Fig. 5 にプロットした。本研究および泉らが転位にトラッ プされた水素に対応するという Peak\#2 の直線から大きく外 れた点に位置している。すなわち, 鈴木らの報告と本研究と で転位にトラップされた水素の放出ピーク温度の解釈が異な ることについては，(1) 式における昇温速度の違いでは説明 できない。試料の純度, 水素導入法, 分析装置が大きく異 なって抽，どの条件の違いによってこのような差が生じた かここでは詳しく考察することはできなかった。

次に高温側のピークについて考察する。高温側のピークは, Fig. 5 でブリスタ（ふくれ）に対応する直線上に位置した。今 回使用した試料の表面にはブリス夕の生じた形跡はなかった が，多くの焼なましした展伸材の内部には $\mu \mathrm{m}$ オーダのポア が存在することが明らかになっている ${ }^{14)} 。$ サイズの違いは あっても, ブリス夕あポアあ水素の存在状態としては気体 （分子状）で同じである。したがって本研究の場合む，ふく

*1 梅田らの測定はバルク材について不活性ガス気流融解熱伝導度 法で求めたものであり, Fig. 2 について述べたようにTDS で求 めた本研究結果との絶対值の比較は困難である。

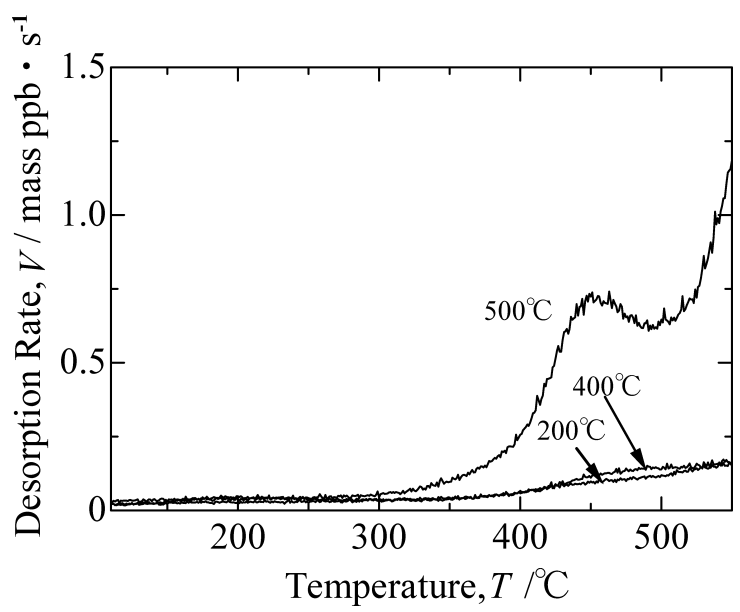

Fig. 6 Thermal desorption spectra for hydrogen gas taken from step (16) shown in Fig. 1 (c).

れを伴わないポアが形成され, それらにトラップされた水素 が放出することにより $550^{\circ} \mathrm{C}$ のピークが表れたと考えられる。 一方で, 梅田ら ${ }^{8)}$ は, $4 \mathrm{~N}$ 純アルミニウムを大気中（湿度不 明）で焼なましした場合に水素量が逆に 0.07 mass ppm から 0.03 mass ppm に減少することを報告している。本研究では, 焼なまし前に脱水素処理により水素量を 0.02 mass ppm まで下 げ， $500^{\circ} \mathrm{C}$ の大気中 $(\mathrm{RH} 50 \%)$ で焼なましすることにより， 0.15 mass ppm まで増加することが明らかになった*1。このよ うに焼なまし前の材料中の水素量により, 水素が侵入するか 放出されるかの挙動が異なることになる。一方, 焼なまし雾 囲気 (大気) の湿度の影響については, 本研究では湿度の増 加とともに水素侵入量が増加する結果となったが, 本試験よ り大幅に湿度を变えた梅田ら ${ }^{15)}$ の結果では湿度にほとんど 影響されていない。このことも焼なまし前の材料中の水素量 が水素の侵入・放出挙動に大きく影響することを示している。

Fig. 6 に, Fig. 1 (c) に基づき $25^{\circ} \mathrm{C}$ における RH $40 \%$ の大 気を循環させながら各温度で $1 \mathrm{~h}$ 焼なましした後に得られた 水素脱離スペクトルを示す（焼なまし温度 $500^{\circ} \mathrm{C}$ のスペクト ルは Fig. 5 の 40\%のスペクトルの再掲)。200, $400^{\circ} \mathrm{C}$ では, $500^{\circ} \mathrm{C}$ と異なり明瞭なピークは現れないが, 脱水素処理後 （焼なまし前）（Fig. 2 参照）に比べ水素量は全体的に増加し ている。これは, 試験片が各焼なましの前後に RH $40 \%$ の室 温大気に暴露されるので Fig. 1（a）（5）に比べて暴露時間は 短いものの同様の水素の侵入が起こり, 加えて焼なまし中に 屯水素の侵入が起こるためと考えられる。この焼なましと大 気暴露のどちらが水素の侵入量へ支配的に影響するかを調べ るため, Fig. 1（d）（17）に示す RH 40\%の大気に $1 \mathrm{~h}$ の暴露 を行った。その後の TDS スペクトルを Fig. 7 に示す。困に は比較のため Fig. 1（a）（6）と Fig. 1（c）（16）のスペクト ルも示した。この結果から, 大気に $1 \mathrm{~h}$ の暴露は $400^{\circ} \mathrm{C} て ゙ ~ 1 \mathrm{~h}$ の焼なましに比べ水素の侵入量は少ないことがわかる。しか しながら, 脱水素処理直後 (Fig. 1（2））に比べると, 大気 $1 \mathrm{~h}$ の暴露によって水素量が明らかに増加していることから, 焼なましと短時間の大気暴露の両方が水素の侵入量に寄与す ると考えられる。 


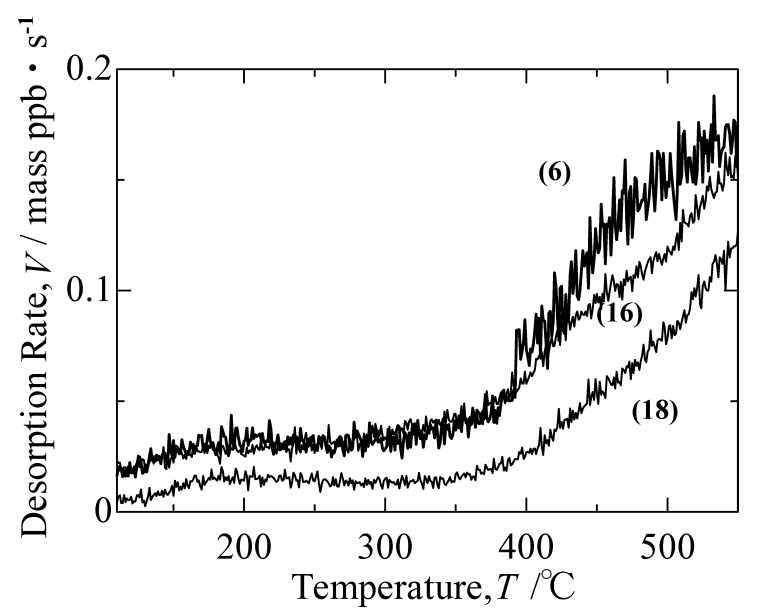

Fig. 7 Thermal desorption spectrum for hydrogen gas taken from step (18) shown in Fig. 1 (d). The spectra taken from steps (6) and (16) are shown for comparison.

\section{4. 結言}

あらかじめ内在水素を脱離させた高純度アルミニウム箔に ついて，室温および高温の主に大気に暴露（大気中で焼なま し）し，その過程で侵入する水素の挙動を TDSにより解析 した。まず室温で超高真空, 大気, 純水に暴露した後にTDS を行った結果, 大気, 純水の環境下に暴露した試験片で水素 放出が確認された。これより, 暴露により表面に付着したり 水和膜の形で存在する水分がアルミニウムとの反応により水 素となり，箔の内部に侵入することが明らかになった。次に， 相対湿度 $40 \%$ の大気中 $500^{\circ} \mathrm{C}$ で $1 \mathrm{~h}$ 焼なましした後に TDSを 行った結果, 443 および $560^{\circ} \mathrm{C}$ に水素の放出ピークを確認し た。これらのピークについて, 温度, 昇温速度から解析した 結果, 低温側のピークは転位にトラップされた水素, 高温側
のピークはポア中に存在する水素に起因するあのと考えられ た。低温側のピークは, 雾囲気の湿度が高くなるほど増大し た。以上のことから, 大気, 純水への暴露抢よび，大気中で の焼なましにより脱水素処理した高純度アルミニウム内部に 水素が侵入し, 転位やポアにトラップされることが明らかと なった。

おわりに，本研究で用いた高純度アルミニウム箔試験片は， 三菱アルミニウム株式会社よりご提供いただいたことに感謝 いたします。また，財団法人軽金属奨学会の教育研究資金に よって行われたことを記し，謝意を表します。

\section{参 考 文 献}

1）高野俊夫：水素利用技術集成 製造・貯蔵エネルギー利用, エ ヌティーエス, (2003), 260-274.

2）伊藤吾朗，菅野幹宏：金属，66 (1996), 599-610.

3）大崎修平, 池田 淳, 木下勝之, 佐々木侑慥：軽金属, 56 (2006), 721-727.

4）一谷幸司, 小山克己, 伊藤吾朗, 大崎修平, 薮田 均：軽金属 学会第 114 回春期大会講演概要, (2008), 351-352.

5）伊藤吾朗，泉 孝裕，遠山拓史：軽金属，58 (2008), 15-21.

6) 泉 孝裕: 茨城大学平成 19 年度博士学位論文, (2007), 28-40.

7）鈴木啓史, 小林大輔, 花田信子, 高井健一, 萩原行人：日本金 属学会誌, 74 (2010), 65 .

8）梅田秀俊，伊藤吾朗，加藤良則：軽金属， 56 (2006), 423-428,

9）大西忠一：軽金属, 39 (1989), 235-251.

10）泉 孝裕, 伊藤吾朗, 亀谷一広, 渡辺英雄 : 軽金属, 58 (2008), 229-235.

11）鈴木秀次：転位論入門，（1983）, 336-341.

12）市村 稔, 今林 守, 早川正広：日本金属学会誌, 43 (1979), 876-883.

13）伊藤吾朗, 鈴木智弥, 河金 慧, 伊藤伸英, 薮田 均：軽金属 学会第 115 回秋期大会講演概要, (2008), 375-376.

14）小林正和, 戸田裕之, 南 恵介, 森 豊和, 上杉健太朗, 竹内 晃久，鈴木芳生：軽金属，59 (2009), 30-34.

15）梅田秀俊，伊藤吾朗，加藤良則：軽金属， 57 (2007), 203-209 